\title{
メタボリックシンドロームに対する食事療法と運動療法の比較
}

\section{田中宏 暁}

\author{
(福岡大学 スポーツ科学部 運動生理)
}

メタボリックシンドロームは内臓脂肪の過剩蓄積を主 因とした，アディポサイトカインの分泌異常による代謝 不良状態であるとされている。 その説に従えば食事制限 によって内臟脂肪を減少させることで代謝不良状態を改 善することができる. 食事制限で骨格筋適応が起こる可 能性を示唆する研究があるものの筋の委縮を伴う可能性 が否定できない。一方運動トレーニングは内臟脂肪の減 少に寄与するだけでなく, 筋の適応はじめ内臟脂肪とは 独立して代謝不良の改善に寄与する可能性があり，それ ぞれ異なる機序での効用があるものと推察される。この ような視点にたち，筆者たちは中年から高齢の生活習慣 病患者とメタボリックシンドロームの判定基準を 1 つで も満たすものを対象に, 食事制限と運動トレーニングの 効果を比較することで，それぞれの特徵を見出すことを 目的として研究を行った。対象者は40歳以上の生活習慣 病患者とメタボリックシンドロームの判定基準を 1 つで も有する男女とした，対象者を運動トレーニング群と食 事制限群に無作為に割り付け，それぞれの 3 か月の効果 について比較を行った.

介入の前後で採血を行い, 血糖值，インスリン，中性
脂肪, HDLコレステロールと, アデイポサイトカイン の測定をした．また血圧測定，水中体重法による体脂肪 率と除脂肪体重の測定, CTによる内臓脂肪面積の評価 さらに運動負荷試験を実施して有酸素性作業能力の測定 を行った運動トレーニングは乳酸間值強度で週当たり 300分を目標にした。トレーニングの支援のために 1 回 60分の運動教室を開催し, 対象者は週 3 回の参加を義務 付ける。また自宅でのトレーニングの支援のためにス テップ台と心拍モニターを貸与し, 日誌によりトレーニ ングの実施状況を把握した。

食事制限は週に 1 回, 管理栄養士の指導の下に実施す る. 対象者の摂取カロリー（kcal）はBMIが22に相当す る体重（理想体重）に25を掛け合わせた数值とする，対 象者は 1 週間のうち 3 日間の食事の記録を取り，栄養指 導のための資料とした。食事制限と運動はいずれもおお むね同等の効果があったが, 運動はHDL, FFAの改善, 有酸素能の向上，骨格筋保持に有効で，食事制限は筋委 縮を伴い，除脂肪体重が減少した，両療法それぞれのメ リットを生かすことが望ましいとの結論を得た。 